University of Minnesota Morris Digital Well

University of Minnesota Morris Digital Well

\title{
Reflections on Reflections: Dialectical Commentaries on Gender and Class in NTAE Production
}

Donna Chollett

University of Minnesota - Morris, cholledl@morris.umn.edu

Follow this and additional works at: https://digitalcommons.morris.umn.edu/anthropology

Part of the Gender and Sexuality Commons, Latin American Studies Commons, and the Social and Cultural Anthropology Commons

\section{Recommended Citation}

Chollett, Donna, "Reflections on Reflections: Dialectical Commentaries on Gender and Class in NTAE Production" (2011). Anthropology Publications. 10.

https://digitalcommons.morris.umn.edu/anthropology/10

This Article is brought to you for free and open access by the Faculty and Staff Scholarship at University of Minnesota Morris Digital Well. It has been accepted for inclusion in Anthropology Publications by an authorized administrator of University of Minnesota Morris Digital Well. For more information, please contact skulann@morris.umn.edu. 


\title{
Reflections on reflections: dialectical commentaries on gender and class in NTAE production
}

\author{
Donna L. Chollett
}

We can appreciate Gunawardana's reflections on "Renegotiating gender and class in the berry fields of Michoacán, Mexico" for providing a broad, global sweep on the nature of industrialization within which my own work is situated. We need both these encompassing accounts and the complementarity of specific, regional histories as well as more ethnographically-grounded understandings to frame the wider patterns of change without losing sight of human actors and the specific diversities in forms of social, economic, and political transformations. As Roseberry's (1989) critical admiration of Eric Wolf's (1982) work clarified, Wolf accomplishes the daunting task of a global synthesis that encompasses structural transformations and processes of power and domination from a Marxist perspective, yet the short cycles and cultural questions are neglected in his presentation of long cycles of structural changes. Gunawardana also raises three issues regarding migration, resistance, and "race."

Gunawardana rightly questions the important issue of migration and we want further insight into how migration, class, and gender intersect dialectically. It would be erroneous, however, even in a historical moment of globalization and free trade, to a-priori assume that particular regions share an essentialized history of labor migration with other parts of the global system of flexible labor fed by patterns of migration. The maquiladora zone has not been a primary destination of either men or women in the Los Reyes region. Eighty-seven percent of households in the research community have sent from at least one to multiple family members into migration streams. Two-thirds of these are men and one-third women, yet only four percent identified Tijuana or the border region as their destination. Only one woman had worked in the maquiladora zone. We must recall the agency of women in making migration decisions to a border characterized by flexible labor and exploitation. When higher wages ensure more income in the North than in the maquiladora zone, migrants calculate the risk and cross the border, often illegally - even when their illegal status subjects them to other forms of subordination. Femicide also overwhelms the border region, providing another logic for avoiding maquiladora labor.

Another important factor is the demand for cheaper labor in the U.S. and the complex practices used by agribusinesses, packing houses, and factories to ensure a steady flow of this reserve army of surplus labor (an increasing percentage of which is women). Even so, it is men who most often migrate to earn higher wages in the U.S., leaving women at home to care for children and households. This same paternalism results in the fact that fewer women migrate, and among those who do, it is often to follow spouses to either internal or external destinations; women claim their primary motive for migration is to be with spouses. Over 80 percent of migrants from Los Angeles have headed not for the border, but instead, for California (most often Los Angeles, CA) to work in agriculture, packing plants, factories, and for men, as mechanics, plumbers, gardeners, and in construction. Thirty-seven percent of women migrants in the U.S. migrated with husbands and remain homemakers, while a few work as maids, in agriculture, packing plants, and factories. When entire families migrate, a greater portion of earnings is spent maintaining the family in the U.S., rather than investing it into households, agriculture, or small enterprises in Mexico; remittances may help to lessen class disparities in the migrant-sending community under conditions of differential male and female migration. With some exceptions, then, class (concentration in underpaid labor) and gender (women's primary role still expressed in the home) remain viable ideological and material forces for Los Angeles migrants in the U.S.

Similar gender ideologies and practices that permeate berry labor in Michoacán shape the greater employment of migrant men than migrant women. Leacock's (1997) feminist Marxist insight is helpful here. The structure of gender relations follows from particular histories and arises along with class inequalities, thus capitalism rearranged gender relations through a patriarchal bargain that rewarded men as breadwinners and devalued women's labor in the household. Women's unpaid labor became a gift to the dominant class, enabling even greater extraction of surplus value. Although we must not skirt the issue of women's paid and unpaid labor contributions, they also reproduce the labor force that is a requisite for continued capitalist production. The resultant ideology supports the resistance to women's work outside of the home evidenced among many berry pickers' male partners. 
Whether forms of resistance are overt (strikes, rebellions, etc.) or more subtle (work slowdowns, spirit possession, etc.), we want to understand the multiple ways in which women organize to resist forces of flexibilization and labor exploitation. Certainly some women challenged gender constructions of public/private and male egos as breadwinners by defying husbands who objected to their waged labor. Others confronted bosses over underpayment. Yet as much as we might like to seek the clues for gendered and classed struggles that Gunawardana desires, I offer two cautions. First, in regard to conditions that may approximate "primitive accumulation" (see Powell's comments) among "working class women," we may ask, as did E.P. Thompson (1963), whether the women berry workers are fully subjected to factory discipline. They may form a rural proletariat, representing formal subsumption to capital (Marx 1977[1867]) within a transnational capitalist regime, yet it could be argued that given the "newness" of waged work in NTAE production in this region, the transition, seen as process rather than product, may be incomplete for campesina women's identities and strategic organizing. We have ample evidence of women's agency in well-established assembly-line contexts. Women berry pickers, however, expressed reluctance to confront bosses for fear of being fired. In Los Angeles, as pointed out in my original work, the absence of union organizations in NTAE production, labor fragmentation, and separation into nine distinct agribusinesses and multiple private bosses has undermined organized class struggle. Resistance, in this specific locality, is of a different nature than in a maquiladora with "official" or independent unions (Bacon 2004), a more long-standing subsumption of labor to capital, and a single corporation as target.

Second, regarding my research on the social movement in Puruarán, Michoacán, I argue that scholars enamored with the morally noble causes and democratic strategies of social movements often seek out counterhegemonic struggles without examining the internal dynamics and failure to enact democratic practices (Hellman 2008, Rubin 1998, Stahler-Sholk et al. 2008). Being desirous of finding challenges to capitalist hegemony does not constitute evidence for them; we merely enter the terrain of wishful thinking. While domination is never complete, in particular circumstances, it may swamp out class struggles and resistance movements. Moreover, cross-border organizing is strong in Mexico, especially in regard to maquiladora labor. One example, among others, is the Support Committee for Maquiladora Workers in San Diego that united with Mexican maquiladora workers, using NAFTA labor side agreements, to bring about labor reform (Bacon 2004). Here too, an aim to seek out such organizing requires not wishful thinking, but evidence, and Los Angeles not only lacks proximity to the U.S. that would facilitate transnational resistance movements, but even the mill closing failed to result in conjoining workers in a united front against mill closings in seven cane-producing localities. What we may "like to have seen more of" failed to accrue (yet?) in this specific locality. Indeed, as suggested in my original work, union organization, class struggle, and militancy under the cane regime (e.g., sequestering of the mill manager) may have partly contributed to the closure of the San Sebastián sugar mill and the reconstitution of labor in female-gendered terms and in the absence of structures and networks that could facilitate resistance movements. Some Marxists romanticize workingclass struggle and have difficulty coming to terms with hegemony if it appears to limit resistance.

Since "race" is not a biologically valid concept as applied to human populations, ethnicity is a more appropriate concept for examination of ethnicity-gender-class dialectics. Here, essentialist categories are of little use to explicate domination and power, whether during the conquest, colonialism, the hacienda system, or contemporary labor in NTAE production, for in doing so, it ultimately robs women (or men) of their historical and political agency (Mohanty 2004). Women reported that their entry into berry labor increased their capacity to earn income, offered liberation from the household, and increased their decision making, self-confidence, and self-esteem, suggesting that their agency as actors, albeit in a capitalist framework, was not entirely absent. Nonetheless, capitalism and patriarchy function together to promote class, gender, and ethnic oppression wherein globalized NTAE production itself constitutes classed, gendered, and ethnic expressions of capitalist patriarchy (Caraway 2007, Ho 1999). Such structural relations may limit women who are simultaneously subordinated on the basis of class, gender, ethnicityor any other characteristic - in their capacity to exert "power to" confront oppressive systems and achieve their goals (Kabeer 2001). The fact that power and dominance can operate through consent and complicity as well as through coercion and conflict is basic to a Gramscian understanding. Women of low class status and marginalized ethnicity in patriarchal systems may lack alternative opportunities for overt resistance which could result in job loss. Both mestizo and Tarascan women may have as much to lose from the disruption of social relationships as they have to gain by challenging patriarchy and capitalist oppressions (Kabeer 2001).

Although all the women in my Los Angeles sample were mestizos, "Women are constituted as women through the complex interaction between class, culture, religion and other ideological institutions and frameworks. They are not 'women' - a coherent group - solely on the basis of a particular economic system" (Mohanty 2004: 30). Ethnicity, gender, and class intersect in multifarious ways in restructuring hegemony and resistance (Ong 1987, Leacock 1997). As Dore (1997) clarifies, class, ethnicity, and gender are multidimensional and intersect as they are mutually constructed through ideological (e.g., marginalizing discourses) and material processes (e.g., extraction of 
surplus value in the case of capitalism and of free labor in the case of domestic labor and creation of use value for family reproduction). Women's labor is devalued vis-à-vis that of men (their work is easier, thus deserving of lower pay), mestizo women are devalued by U.S. and Chilean bosses (by exploitation wages), Tarascan women devalued vis-à-vis mestizo women ("they have a very low culture"), and all are subject to extraction of surplus value based on their class positions. My research examines how these dimensions are cross-cut by the diverse positions among women based on age, marital status, life cycle stage, household makeup, and class fraction.

As I am sure Macip is well aware, there are different readings of Marx (cultural, economic, political, etc.); indeed, any work is subject to multiple interpretations. To read Marx politically, one generally prioritizes production, where class relations constitute the very basis of dialectical conflict. As to Macip's first issue, the focus turns to consumption as he minimizes the importance of commodity fetishism and consumer nescience. A vast literature (which I will not cite here) recognizes that few people consider the externalities embedded in commodities, which may include exploited social labor, environmental degradation, and political disruption, let alone the fetishization of the price. This is a widely recognized fact among scholars of the global food system. Given the domination of transnational corporations over this system, Macip correctly implies that a revolutionary change in challenging and overturning this system is sorely needed, yet unlikely in the near future-until the current system becomes completely unsustainable.

I would take issue with his interpretation that any resistance on the part of informed consumers would merely constitute a pre-political reaction to Christian guilt/social shame. If we accord agency to various movements that are resisting globalization and challenging this global food system (recall the Seattle and other WTO demonstrations) and through viable alternatives (farmers markets, CSAs, organic farms, etc.) the movement is not insignificant even though it has not toppled the hegemonic system. However, neither this is central issue when we recall that the relationship that is partially propped up by commodity fetishism (NTAE production would not be viable if there were no consumers) is also a political relationship between labor and transnational capitalism. The commodity fetishism, taken politically as the "unseen" externalities of labor exploitation and environmental devastation, becomes a hidden subsidy to polluters and exploiters (transnational agribusinesses), allowing them to augment their extraction of surplus value in regions of cheap labor and non-existent or non-enforceable environmental controls (Pretty 2002). We can read this account politically if we do not lose sight of the fact that labor makes these commodities available and the cost has been extraction of surplus value. If we take Roseberry's (1989: 31) insistence on a "Marxist understanding of culture and a cultural reading of Marx" seriously, where dialectically "action is shaped by meanings people take to their action even as meanings are shaped by people's actions" (1989: 33), we have not a "cultural reproach," but an understanding of the mutual shaping of cultural understanding and unequal power wherein culture becomes a material force at the intersection of global-historical processes. I suspect that Macip may have something like Roseberry's critique of Wolf in mind when he asks for "a coordinated political effort to dismantle the current conditions of production." Roseberry states, "We want to know more. We will want to see anthropological subjects not only as products of world history, but also as actors in their history" both accommodating and resisting (1989: 140). Like the wishful thinking of some social movement theorists, we cannot know more of such movements until they materialize in specific times and places. A political reading leaves us with oppressive work conditions and remunerations of this new labor force and yet unrealized resistances of a revolutionary scale. Frankly, the dismantling of the global food system most likely will be brought on by the inability of the global system to ecologically sustain it, in other words, capitalist greed will become its own gravedigger.

Macip's critique implies that Marxist scholars have spilled (perhaps too) much ink on extraction of surplus value; this should hardly surprise us since this "normalcy" is the raison d'être of capitalist production. He also rightly points out the significant difference in the sugar regime and the berry regime, one based more on male labor and the other on a more "feminized" labor force. Feminists have also written extensively on this topic through a Marxist framework. For some, with the wedding of Marxism and feminism, “...gender was brought in through the back door of patriarchy, so capitalism...remained a gender-blind system” (Caraway 2007: 9). Thus, female gender may be invoked, but jobs become gendered not by ideology, but on the basis of profitability. Gendered images in fact shape and create a docile labor force through the processes of labor (Salzinger 2003). Rather than entering the labor force as a pre-conceived, gendered subject, berry workers (as well as maquiladora workers) are created through a dialectical labor process in that as they create value for capital, they lose value as workers; the woman worker is being produced along with the commodities (Wright 2006). We may dismiss culturally-constructed gender myths to a cultural reproach, but the creation of "women workers" contributes to the materialization of global capital, a process that is intrinsic to a Marxist framework.

Mancip's final comments on the "uncertain future" of the Los Reyes region are well placed when we consider current conditions within a historical, Marxist framework. Export commodities have always been subject to the 
whims of natural and climatic factors, economic perturbations of the market, shifting global demands, and boom/bust cycles-NTAEs are no exception. But they are also permeated by differential power and unequal class systems. The neoliberal erasure of social support, basic rights, marginalization of rural communities, and the expulsions from rural Mexico are experienced as both subjective and material processes that cannot be denied. An initial attempt by berry growers to form an organization to export fruit independently of the agribusinesses failed due to opposition of the capitalist sector and internal dissention among growers. However, neither can we deny social organization and struggle as an essential force for challenging dominant systems. Should the industry survive, perhaps in the future growers and workers will form independent unions (as did a few maquiladoras on the border) to fortify their bargaining power and press their demands. Neoliberalism is but one phase in a long history of labor organization and resistance.

Powell's very perceptive arguments point to the fallacy of understanding "gender" solely as a social construct for women, a misrepresentation too common in feminist literature. Examination of women's subaltern positions must be accompanied by analysis of the subaltern positions of men (Caraway 2007; Chant 2003). The critical analytic must remain the relationship between men and women: the masculine subject becomes a male worker only through the materialization of the woman worker who stands in opposition to him in the gendered division of labor (Wright 2006). Moreover, we want to dispose of an analysis that "assumes men and women are already constituted as sexual-political subjects prior to their entry into the arena of social relations" (Mohanty 2004: 26).

To expand on the work of Leacock (1997) and Dore (1997), cited above, like women, men's identities are over determined as husband, father, breadwinner, worker, unemployed male, mestizo, Tarascan, union member, berry grower, migrant, and innumerable other social constructions. The fact that sugar cane was legally declared in the public interest in the Decreto Cañero shaped cañeros' identities and social roles as producers of a vital national export commodity, even as mill workers and the rural proletariat became economically differentiated from cañeros. Women cañeras enjoyed the same rights as union members, but union meetings were predominantly maledominated. Powell makes an excellent point that the norms for acceptable public/private activities tied males more closely to national-level union leaders and the (formerly) PRI-dominated unions, thus enhancing their position. Nonetheless, the patriarchal bargain, where men were subordinated to the capitalist labor market and dependent women to men, accorded to all laboring men a pride in their role as breadwinners.

We must also question traditional feminist Marxist constructions of gender, even as they provide critical understandings for gender and class formation. Even Leacock's work (1997) perpetuates the dualism of private/public, reproduction/production constructions. Guttman (1996) offers a rare, but relevant critique of this binary. He asks why social reproduction, socialization of children, and nurturing relationships are not attributed to men? Indeed, why are remittances sent by male migrants not considered as part of family reproduction? Reinforced by agribusinesses, such binary constructions enable misconceived gendered ideologies and facilitate the differential insertion of men and women into the regional economy.

Aside from these cultural expressions (which again, serve as material forces in the process of production), agribusinesses promote this myth of gender differences - even though some men do pick berries - because men demand higher wages to ensure family reproduction, which in turn diminishes the profits of employers. In terms of out-migration, with the dramatic expansion of strawberries and raspberries in California (Driscolls) and Oregon (Hursts), migrants provide the social labor that subsidizes U.S. agriculture, as Mexico subsidizes reproduction costs (education, health care, labor, etc.) that the U.S. does not have to compensate. At the same time, remittances help to preserve rural communities in Mexico. Men (and increasingly women), who spurn "women's labor" in Mexico, work in U.S. berry fields excessive hours for five dollar a day, with inadequate housing, and with none of the social benefits of U.S. citizens. Yet they engage in similar labor processes that "the myth" informs them they must not undertake in Mexico.

As men lost their role as cane growers with closure of the sugar mill, women's employment challenged their positionality as breadwinners. Men often opposed spouses and daughters' entry into paid labor, but berry growers confront the contradiction of hiring women for berry picking, yet denying spouses the right to waged labor ("not our women"- as suggested by Kathy Powell, personal communication), illustrating the complexity of class fractions in the region. We can discern from these processes that some aspects of male dominance were strengthened, while others were weakened. Individuals may be dominant in some respects, but subordinate in others; class, gender, and ethnic statuses are not monolithic, but multifaceted and constantly emergent. 


\section{References}

Bacon, David. 2004. The Children of Nafta: Labor wars on the U.S./Mexico border. Berkeley: University of California Press.

Caraway, Teri L. 2007. Assembling Women: The Feminization of Global Manufacturing. London: IRL Press.

Chant, Sylvia. 2003. Gender and Employment. In Gender in Latin America, eds. Sylvia Chant and Niki Craske, 194227. New Brunswick: Rutgers University Press.

Dore, Elizabeth, ed. 1997. Gender Politics in Latin America. New York: Monthly Review Press.

Guttman, Matthew. 1996. The Meanings of Macho: Being a Man in Mexico City. Berkeley: University of California Press.

Hellman, Judith Adler. 2008. Mexican Popular Movements, Clientelism, and the Process of Democratization. In Latin American Social Movements in the Twenty-First Century, eds. Stahler-Sholk, Richard, Harry E. Vanden, and Glen David Kuecker, 67-76. New York: Rowman \& Littlefield.

Ho, Christine G.T. 1999. Caribbean Transnationalism as a Gendered Process. Latin American Perspectives 26(5): 34-54.

Kabeer, Naila. 2001. Resources, Agency, Achievements: Reflections on the Measurement of Women's Empowerment. In Discussing Women's Empowerment: Theory and Practice, ed. Anne Sisask, 17-57. Stockholm: SIDA.

Leacock, Eleanor Burke. 1997. Feminism, Marxism, and History. In Visions of Culture, ed. Jerry D. Moore, 201209. New Brunswicke: Altamira Press.

Marx, Karl. 1977[1867]. Capitol, V. I. New York: Random House/Vintage.

Mohanty, Chandra. 2004. Feminism without Borders: Decolonizing Theory, Practicing Solidarity. Durham: Duke University Press.

Ong, Aiwa. 1987. Spirits of resistance and capitalist discipline: Factory women in Malaysia. Albany: State University of New York Press.

Pretty, Jules. 2002. Reality checques. In Agri-culture: Reconnecting people, land and nature, ed. Jules Pretty, 51-57. London.: Earthscan.

Roseberry, William. 1989. Anthropologies and Histories: Essays in Culture, History, and Political Economy. New Brunswick: Rutgers University Press.

Rubin, Jeffrey. 1998. Ambiguity and Contradiction in a Radical Popular Movement. In Cultures of Politics, Politics of Cultures: Re-Visioning Latin American Social Movements, eds. Sonia E. Alvarez, Evelina Dagnino, and Arturo Escobar., 141-164. Boulder: Westview Press.

Salzinger, Leslie. 2003. Genders in Production: Making Workers in Mexico's Global Factories. Berkeley: University of California Press.

Stahler-Sholk, Richard, Harry E. Vanden, and Glen David Kuecker. 2008. Introduction. In Latin American Social Movements in the Twenty-First Century, eds. Richard Stahler-Sholk, Harry E. Vanden, and Glen David Kuecker, 1-15. New York: Rowman \& Littlefield.

Thompson, E.P. 1963. The Making of the English Working Class. New York, Pantheon Books

Wolf, Eric. 1982. Europe and the People without History. Berkeley: University of California Press. 
Wright, Melissa W. 2006. Disposable Women and Other Myths of Global Capitalism. New York: Routledge. 